\title{
Valtion legitimiteetti ja kansalaiskasvatus
}

\section{Suomen ja Venäjän koulutuspoliittisissa asiakirjoissa 1990-2000-luvuilla}

\begin{abstract}
$+y$
Koulutuspoliittinen vertailututkimus analysoi kansalaiskasvatuksen roolia Suomessa ja Venäjällä 20 vuoden aikajaksolla. Useista eroistaan huolimatta molemmat maat antavat yhä suuren arvon kansalaisuudelle ja kansalliselle identiteetille.
\end{abstract}

\section{JOHDANTO}

Kansainvälisessä, vuosina 1995-1999 toteutetussa yhteiskunnallisen oppimisen tutkimuksessa väitetään: "kansalaiskasvatus ja yhteiskunnallinen osallistuminen ovat nousseet Euroopassa tällä vuosikymmenellä tapahtuneiden nopeiden muutosten seurauksena laajan kansainvälisen mielenkiinnon ja tutkimuksen kohteeksi" (International Association for the Evaluation of Education Achievement IEA/ Civics-tutkimus 1999).

Tämä kehityssuunta on näkynyt myös Suomessa ja sen naapurivaltiossa Venäjällä. Sekä Venäjällä että Suomessa on 1980-luvun puolivälistä alkaen koettu merkittäviä valtioon ja yhteiskuntaan vaikuttaneita mullistuksia. Neuvostoliiton romahdettua Venäjä on pyrkinyt löytämään uusia tapoja valtiollisen yhtenäi- syyden ylläpitämiseksi, valtion uudelleen rakentamiseksi ja maan kansainvälisen aseman parantamiseksi. Suomessa puolestaan Euroopan yhdentyminen, taloudellinen epävakaus ja lisääntyvä maahanmuutto ovat asettaneet muutospaineita kansalaisuudelle ja kansalliselle identiteetille.

Tässä artikkelissa tarkastellaan Venäjän ja Suomen poliittista ja kansallista sosialisaatiota (joista jatkossa käytetään yhteisnimikettä kansalaiskasvatus) ohjaavaa koulutuspolitiikkaa 1980-luvun puolivälistä vuoteen 2007. Analyysi perustuu oppivelvollisuuskoulun toimintaa ohjaavaan koulutuspoliittiseen aineistoon, joten järjestöjen ja muiden koulutusasteiden kansalaiskasvatuksellinen toiminta jää tämän tarkastelun ulkopuolelle. Artikkeli pohjautuu vuonna 2010 valmistuneeseen väitöskirjatutkimukseeni (Piattoeva 2010a). 
Sen sijaan, että pohtisin poliittisten muutosten vaikutuksia kansalaiskasvatuksen päämääriin tai sisältöihin lähestyn kansalaiskasvatuspolitiikkaa eräänlaisena ikkunana yhteiskunnan laajempiin kehityslinjoihin. Pyrin ennen kaikkea vastaamaan kysymykseen, miten valtion, kansalaisuuden ja kansallisuuden väliset suhteet ja näiden käsitteiden sisällöt ovat muuttuneet koulutuspoliittisten asiakirjojen valossa Suomessa ja Venäjällä. Tutkimusta voidaan siis lukea ikään kuin kansalaiskasvatuspolitiikan mikronäkökulmasta kirjoitettuna analyysina suomalaisen ja venäläisen yhteiskunnan ja valtion kehityksestä viime vuosikymmeninä.

Tutkimuksen punaisena lankana on kansalaiskasvatuksen ja valtion legitimiteetin välinen side. Valtion legitimiteetillä tarkoitan valtiovallan hyväksyntää kansalaisten silmissä. Suomen ja Venäjän 1990-2000-lukujen yhteiskunnallisia konteksteja yhdistää valtion legitimiteetin heikentyminen ja kansalaisten ja valtion suhteen laadun muutokset. Kansalaiskasvatuksen nousu tärkeäksi poliittiseksi ja pedagogiseksi aiheeksi näkyy sitä koskevien ministeriöiden ja johtavien poliitikkojen tekemien linjausten määrässä. Nämä linjaukset heijastavat valtiovallan pyrkimyksiä legitimiteettinsä vahvistamiseksi ja kansalaisten luottamuksen palauttamiseksi (Venäjän tapauksessa voidaan tarkemmin sanoa 'uudelleen luomiseksi'). Kansalaiskasvatuksen lähestyminen valtion legitimiteetin näkökulmasta tekee näkyväksi kasvatuksen peripoliittisen luonteen. Tämän näkökulman ansiosta voimme nähdä myös koulutusjärjestelmän ja yhteiskunnan välisen suhteen. Koulutusjärjestelmä muun muassa paljastaa peilinomaisesti yhteiskunnallisia muutosprosesseja.

Olen väittänyt tutkimuksessani (Piattoeva 2010b, 70), että kansalaiskasvatus edustaa poliittisesti herkintä ja ristiriitaisinta koulutuspolitiikan ja pedagogiikan aluetta. Sen vuoksi lähestyn kansalaiskasvatusta yhtäältä kilpailevien poliittisten ideaalien kohtauspaikkana ja taistelukenttänä ja toisaalta katson kansalaiskasvatuksen heijastavan vaihtoehtoisten poliittisten visioiden hetkellistä tasapainoa ja valtiovallan legitimaatiokäsikirjoituksena pyrkimystä vakauteen. Näin ollen kansalaiskasvatus sekä heijastaa ja uusintaa hallitsevaa kansalaiskäsitystä että legitimoi val- tion ja kansalaisten välisen sopimuksen. Kansalaiskasvatuksen kompleksisuutta lisää sen historiallisesti muodostunut tehtävä sekä poliittiseen järjestelmään osallistumiseen valmentavana että kansallista yhteenkuuluvuustunnetta eli ns. kansallista identiteettiä vaalivana pedagogisena projektina. Viittaan tähän kaksijakoisuuteen poliittisen sosialisaation ja kansallisen sosialisaation termein ja väitän, että nämä yhdessä muodostavat kansalaiskasvatuksen kaksi keskeisintä päämäärää.

Artikkelin aluksi tarkastelen poliittisen ja kansallisen sosialisaation käsitteitä. Seuraavaksi kuvaan tutkimuksen metodologisia lähtökohtia. Perustelen Suomen ja Venäjän vertailua ja esittelen tutkimuksen koulutuspoliittista aineistoa, jota olen analysoinut retoriikan ja 'politiikka diskurssina' lähestymistapojen avulla. Venäjän ja Suomen vertailua perustellessani ja maiden konteksteja analysoidessani väitän, että ne edustavat erityyppisiä valtiorakenteita: imperiumia (Venäjä) ja kansallisvaltiota (Suomi). Nämä ideaalityypinomaiset käsitteet eivät kaikilta osin vastaa Suomen ja Venäjän valtiopiirteitä, mutta niiden harkitseva soveltaminen korostaa molempien kansallisten kontekstien erityspiirteitä. Tämän jälkeen keskityn Suomen ja Venäjän kansalaiskasvatuksen esittelyyn ja analysointiin.

\section{KANSALLINEN JA POLIITTINEN SOSIALISAATIO}

Kymlicka ja Straehle $(1999,73)$ väittävät, että kansallisvaltion olemassaolon ja säilyvyyden edellytyksenä on valtion kansakuntaistamispolitiikka (nationalising, nation-building policies), jota toteuttavat eri yhteiskunnalliset instituutiot, kuten media, armeija ja koulutusjärjestelmä. He kutsuvat kansallisvaltiota tämän jatkuvan kansakuntaistamispolitiikan tuotteeksi muistutuksena siitä, ettei kansallisvaltioita ole olemassa ilman eri instituutioiden ja puhetapojen jatkuvaa ja monikerroksista vaikutusta. Kansallisvaltioiden syntyä tutkineet historioitsijat ovat korostaneet koulutusjärjestelmän ja erityisesti oppivelvollisuuskoulun merkittävää roolia kansallisvaltioiden kehityksessä Euroopassa (Hobsbawm 1987; Green 1990; Paasi 1998). Juuri valtion kontrolloima oppivelvollisuuskoulu on perustamisesta lähtien kantanut vastuuta yhtenäisen kansallisen kielen levittämisestä ja kan- 
sallisen muistin luomisesta (opettamalla valikoidusti kansan syntyhistoriaa). Tietoisuus kuulumisesta johonkin isompaan kokonaisuuteen, kuten kansallisvaltioon omine rajoineen, arvoineen ja perinteineen, syntyy osana nationalistista pedagogista projektia. Kuten Anssi Paasi $(1998,217)$ kirjoittaa, ihminen on syntyessään avoin olento, joka sosiaalistuu kansallisiin ajattelutapoihin "sosiaalisen syntymän" kautta. Tätä prosessia Paasi (sama) nimittää "kansalliseksi sosialisaatioksi”.

Poliittinen sosialisaatio terminä on pidettävä erillään poliittisen sosialisaation tutkimuksesta, joka on keskittynyt selvittämään esimerkiksi kiinnittymistä poliittiseen järjestelmään, poliittisten asenteiden, kuten äänestämiskäyttäytymisen periytymistä tai yhteiskunnallisen tietämyksen tasoa, pitäen itse poliittisen sosialisaation prosessia kouluissa, perheissä tai harrastusten parissa kyseenalaistamattomana ja poliittisesti ja eettisesti oikeutettuna (ks. Sigel 1995). Poliittinen sosialisaatio terminä sen sijaan korostaa valtiollisen koulutusjärjestelmän keskeistä roolia poliittisen järjestelmän pysyvyyden turvaamisessa. Erään määritelmän mukaan poliittinen sosialisaatio tarkoittaa erilaisten yhteiskunnallisten toimijoiden välittämää oppimisprosessia, jonka seurauksena yksilö sisäistää hyväksyttyjä asenteita ja käyttäytymisen malleja (Massialas 1977).

Kansalaiskasvatuksen kaksoisluonne juontuu kansalaisuuden muodostumisen modernista historiasta, jonka taustalla häämöttävät sekä edustuksellisen demokratian että kansallisvaltioideologian synty. Kansalaisuus poliittisen yhteisön jäsenyytenä tarkoittaa oikeutta osallistua itsehallintaan ja hallittuna olemiseen eli itseään koskevien päätösten tekemiseen (esim. Kuusela \& Saastamoinen 2006). Edustuksellisen demokratian tulon myötä suoran poliittisen itsehallinnan tilalle nousi niin sanottu representaatiopolitiikka, jossa osallistuminen tapahtuu äänen delegoimisen kautta. Kansalaisuuteen liittyy myös kulttuurisen kuulumisen ulottuvuus, jota kutsutaan kansallisuudeksi. Kansalaisuuden kansallistuminen tarkoittaa prosessia, jonka seurauksena kansalaisuus rajattiin tarkoittamaan tietyn kansallisvaltion jäsenyyttä (Isin \& Turner 2007, 11). Nationalismi kansallisuusaatteena tulkitsi kansakunnan kulttuuriseksi kokonaisuudeksi, jonka jäsenet sekä nauttivat samankaltaisista poliittisista oikeuksista että jakavat tietyn yhtenäisen kulttuurin. Kansalaisuuden kansallistuminen korostuu erityisesti Suomessa, jossa kansalaisuus suomennettiin kansalaisuudeksi painottamaan kulttuuriseen kansakuntaan kuulumista. Suomi onkin yleensä luettu historiattomiin kansakuntiin, joille kansa on tyypillisesti kielellis-kulttuurinen kokonaisuus (Stenius 2003 ja Liikanen 2003 teoksessa Ronkainen 2009, 52).

\section{SUOMEN JA VENÄJÄN VERTAILUSTA}

Tämä tutkimus sijoittuu vertailevan koulutustutkimuksen (comparative education) piiriin ja perustuu niin sanottuun kontrastoivaan vertailevaan tutkimusotteeseen (individualising comparison, contrast of contexts, ks. Tilly 1984 ja Skocpol \& Somers 1980). Kontrastoiva vertailu auttaa ymmärtämään molempien kansallisten kontekstien erityspiirteitä, sillä tutkittavan tapauksen erityisluonne kirkastuu, kun sitä vertaillaan systemaattisesti toiseen tapaukseen. Suomen ja Venäjän kontekstien kontrastoimisen tekee mielekkääksi se, että ne edustavat hyvin erilaisia, elleivät jopa vastakkaisia valtiomalleja ja kansalaisuuden traditiota. Onkin väitetty, että kontrastoivan otteen analyyttinen hyöty kasvaa silloin, kun vertailuasetelman muodostavat mahdollisimman erilaiset tapaukset ja tutkijan huomio kohdistuu ennen kaikkea tapausten selkeimpiin keskinäiseroihin (Skocpol \& Somers 1980, 179). Vaikka vertaileva tutkimus tekee näkyväksi jokaisen kontekstin erityisyyden, se samalla mahdollistaa jonkin yleisen ja yhteisen löytämisen. Tässä tutkimuksessa tapauksia yhdistävänä elementtinä toimii valtion legitimiteetin ja kansalaiskasvatuksen suhteen muutos, ja tutkimuksen tarkoituksena on selvittää, miten kaksi hyvin erilaista valtiota reagoivat samankaltaiseen haasteeseen.

Ajatus valtiovallan legitimiteetin tärkeydestä on peräisin vallitsevasta poliittisesta järjestyksestä, jonka mukaan kansallisvaltio edustaa ainoata hyväksyttyä poliittis-territoriaalisen organisoitumisen ja kollektiivisen identifioitumisen muotoa (Smith 1998, 70). Yksinkertaistaen voi sanoa, että modernien "kansanvaltaisten" valtioiden vallankäyttö perustuu kansan tahtoon (Alasuutari 1998, 158). Moder- 
nia valtiopolitiikkaa voidaankin kiteytetysti kutsua hegemoniataisteluksi oikeudesta edustaa kansaa (vrt. Liikanen 1997, 349). Kansallisvaltion "keskeisiä pilareita ovat suvereenius poliittisesti ja alueellisesti, legitiimi vallan käytön monopoli, poliittinen ja oikeudellinen yhdenvertaisuus sekä yhteinen kieli” ${ }^{1}$. Kansallisvaltion jäsenten, kansalaisten, oletetaan jakavan kulttuurisen yhdenmukaisuuden ja poliittisen lojaalisuuden. (Ronkainen 2009, 18.) Kansallisvaltion ideaalissa paikka, ihmiset, hallinto ja kulttuuri muodostavat kokonaisuuden (Paasi 1998; Ronkainen 2009) ja kansalaisuus ja kansallisuus ovat puolestaan kietoutuneet tiiviisti yhteen.

Toisin sanoen kansalaisten ja valtion välinen suhde, josta voidaan myös käyttää termiä integraatio, rakentuu sekä kulttuurisen yhteenkuuluvuuden että poliittisen osallistumisen myötä. Kansan ja valtion välissä vallitsee eräänlainen sopimus tai vaihtokauppa, jossa kansalainen saa muun muassa turvallisuutta, jatkuvuutta, takeet jonkinlaisesta hyvinvoinnista ja vaikuttamismahdollisuuksista kansallisen identifioitumisen, henkilökohtaisen työpanoksen ja muun osallistumisen, esimerkiksi asepalveluksen, vastikkeeksi (Paasi 1998, 216).

Venäjän tapaus edustaa vastakohtaa sille historiallisesti muovautuneelle ajatusmallille, jonka mukaan sanalla valtio tarkoitetaan kansallisvaltiota. Venäjän edeltäjän - Neuvostoliiton - valtiomalli, josta käytän tutkimuksessani termiä imperiumi, eroaa (Suomen) kansallisvaltioideaalista päinvastaisella käsityksellä kansalaisuuden ja kansallisuuden välisestä suhteesta ja sen alueella asuvien ihmisten poliittisesta integraatiosta. Nyky-Venäjän kansalaiskasvatuksen politiikkaa tutkiessa onkin ensisijaista ymmärtää Neuvostoliiton aikana vakiintuneita käsityksiä, sillä ne muodostavat nyky-Venäjän politiikan lähtötilanteen. Poliittisesti Neuvostoliiton kansalaisten asemalla oli vain näennäinen yhteys kansalaisuuden itsehallintaideaaliin, sillä autoritäärisen valtiovallan alaisina heillä ei ollut mahdollisuuksia osallistua itseään koskevien poliittisten päätösten tekoprosessiin (Suny \& Martin 2001,9). Kulttuurisesti Neuvostoliitto ei pyrkinyt luomaan kielellisesti ja kulttuurisesti yhtenäistä kansaa. Imperiumeille on sen sijaan ollut tunnusomaista monikansallisuus ja yhden vahvan kansan alamaisuudessa toimivien kansojen kirjo (Parrott 1997). Neuvostoliiton tapauksessa 'kansa' tarkoitti lukuisten tasavaltojen ja autonomisten alueiden etnisiä ryhmiä eikä valtion laajuista yhtenäistä väestöä, ja kansallisuus puolestaan kuulumista yhteen näistä lukuisista etnisistä ryhmistä (esim. Bessinger 2005; Brubaker 1996). Neuvostoliiton romahdettua uuden Venäjän keskeisenä haasteena on määritellä se kansa, jota valtiovallan on tarkoitus palvella, sekä ne ideat, jotka sitovat kansalaiset ja valtion legitiimiin keskinäissuhteeseen (Breslauer \& Dale 1997, 307).

\section{TUTKIMUKSEN AINEISTO}

Kansallinen sosialisaatio -termi valottaa koulutuksen merkitystä valtiollisen yhteenkuuluvuuden luomisessa kulttuurisessa ja moraalisessa mielessä, kun taas poliittinen sosialisaatio korostaa koulutuksen keskeistä sijaa kiinnittymisessä poliittisiin instituutioihin. Kansalaiskasvatus kansallisena ja poliittisena sosialisaationa on peruskoulutusjärjestelmän tärkeä tehtävä, sillä valtiollisen koulun syntyhistorialla on vahva sidos kansallisvaltioiden ja modernin poliittisen järjestelmän nousuun. Tämän vuoksi kansalliseen ja poliittisen sosialisaatioon kuuluvia sisältöjä löytyy paitsi monista oppiaineista myös (koulu)arjen päivittäisistä käytännöistä (Arthur, Davies \& Hahn 2008; Aapola, Gordon \& Lahelma 2003).

Tämän laadullisen tutkimuksen tutkimusaineiston muodostavat venäläiset ja suomalaiset koulutuspoliittiset asiakirjat 1980 -luvun lopulta vuoteen $2007^{2}$. Poimin asiakirjoista kansallisuuteen ja kansalaisuuteen viittaavia tavoitteita ja niitä oikeutettavia argumentteja käyttäen apunani retoriikan ja 'politiikka diskurssina' -lähestymistapoja. Koska kiinnostukseni kohdistui en- 
nen kaikkea kansalaiskasvatukseen valtiovallan legitimaatiokäsikirjoituksena, pidin tärkeänä tutkia nimenomaan valtion taholta tuotettuja poliittisia asiakirjoja eli valtion diskurssia kansalaiskasvatuksesta.

Tutkimus liittyy tutkimussuuntaukseen, jota kutsutaan politiikan sisällön analyysiksi (analysis of policy content). Tämäntyyppinen tutkimus keskittyy politiikan taustalla olevien arvojen, oletusten ja ideologioiden selvittämiseen sekä politiikan ja laajemman kontekstin välisen suhteen tutkimiseen (Olssen, Codd \& O’Neill 2004, 72.) Koulutuspoliittinen tekstinanalyysi tarkoitti tässä tutkimuksessa aineiston lähilukua, jonka tavoitteena oli löytää tietylle aikavälille tyypillisiä käsityksiä kansallisuudesta, kansalaisuudesta ja valtiosta (vrt. Olssen, Codd \& O’Neill 2004). Retoriikan analyysin ansiosta dokumenttien tulkinta keskittyi teksteissä käytettyihin tapoihin vakuuttaa lukijaansa. Olin ennen kaikkea kiinnostunut niistä "pakottavista tarpeista" (exigence ks. Edwards, Nicoll, Solomon \& Usher 2004), joilla kansalaiskasvatuksen sisältöjä pyrittiin uskottavasti perustelemaan. Juuri tämän lähestymistavan ansiosta valtiovallan legitimiteetin muutos paljastui tärkeäksi syyksi kansalaiskasvatuksen uudelleen arvioinnille sekä Suomessa että Venäjällä.

\section{KANSALAISKASVATUS SUOMESSA}

Suomessa kansainvälinen Civics-tutkimus ja vuosittain toteutetut Nuorisobarometrit ovat nostaneet esiin yhtältä suomalaisnuorten korkean yhteiskunnallisen tietotason ja toisaalta vähäisen kiinnostuksen politiikkaa ja aktiivista kansalaistoimintaa kohtaan (Brunell \& Törmäkangas 2002; Tomperi \& Piattoeva 2005). Samantyyppistä huolta demokratiavajeesta eli kansalaisten ja erityisesti nuorten alhaisesta kiinnostuksesta kansalaisvaikuttamiseen, äänestämiseen ja jäsenyyteen poliittisissa puolueissa on kannettu muissakin eurooppalaisissa maissa (esim. Kennedy 1997). Civics-tutkimuksen puitteissa on toteutettu suomalaisten koulutuspoliittisten asiakirjojen, opetussuunnitelmien ja oppikirjojen analyyseja, joilla on pyritty taustoittamaan ja osittain myös selittämään kyselytutkimuksen tuloksia. Erittäin valaisevana pidän Suutarisen (2000a, 38) johtopäätöstä, että oppisisältöjä on Suomessa muutettu tai vaihdettu vähän. Hän selittää Suomen eron muuhun Eurooppaan johtuvan poikkeavan pitkäaikaisesta vakaudesta, jonka ansiosta syvällisiä koulutusjärjestelmän muutoksia ei ole tarvittu. Kiinnostus yhteiskunnalliseen kasvatukseen nousi Suutarisen mukaan vasta 1990-luvun alussa Suomen geopoliittisen aseman muutoksen, syvän laman, työttömyyden ja maahanmuuttajien kasvavan määrän myötä.

Suutarisen väittämän valossa on tärkeä pitää mielessä, että 1990-luvun alun koulutuspoliittiset asiakirjat, esimerkiksi Kansallinen sivistysstrategia (1993) ja Humanistis-yhteiskuntatieteellisen yleissivistyksen komitean mietintö (1993), esittivät huolensa yhteiskunnan eheydestä ja konfliktien mahdollisuudesta. Näiden asiakirjojen iskusanoja olivat murros, eheyden purkautuminen ja kansainvälisyys. Sivistysstrategian (sama) mukaan eheyttä purkavia voimia olivat kasvava taloudellinen eriarvoisuus ja monikulttuurisuus. Näkökulmat tuovat mieleen yhtymäkohtia Suomen syntyvaiheisiin, jolloin eheyden pelättiin kärsivän kielellisten erojen ja poliittisten erimielisyyksien vuoksi.

Dokumenteissa käytetyt syyt humanistisyhteiskunnallisen sivistyksen uudelleen arvioinnin tarpeellisuudelle paljastavat, että sen puoleen käännytään poliittisesti epävakaina aikoina, jolloin vakiintunut yhteiskunnallinen järjestys on murroksessa ja valtionvallan legitimiteetti koetaan hauraaksi. Frazer $(1999,2)$ kutsuukin kansalaiskasvatuksen historian osuvasti "moraalisten paniikkien aalloiksi", joiden taustalla on poliittisen tasapainon muutokset ja valtiovallan legitimiteetin kriisiytyminen. Mike Bottery (2003) on esittänyt, että nykyaika edustaa valtion ja kansalaisten välisen sopimuksen purkautumista, sillä globaalin kilpailukyvyn nimissä kansallisvaltiot ovat vähentäneet hyvinvointipalveluja. Samaan aikaan työpaikat ovat siirtyneet halvempien työkustannusten maihin nostaen työttömyyttä ja työnsaantia koskevaa epävarmuutta. Kansalaisten arkeen vaikuttavien poliittisten päätösten areena on monelta osin karannut kansallisen edustuksellisen demokratian ulottumattomiin muun muassa suurille monikansallisille yrityksille ja ylikansallisille poliittisille tahoille (esim. EU, OECD, YK). Poliittisten päätösten aree- 
nojen pirstaloituminen koettiin tärkeäksi myös Suomessa, missä korostettiin edustuksellisen demokratian uusia haasteita päätöksenteon siirryttyä kansainvälisiin piireihin (Kansallinen sivistysstrategia 1993, 8; myös Kansalaisvaikuttamisen politiikkaohjelma 2004, 1).

Valtion ja kansalaisten välisen sopimuksen purkautuessa kuilu valtion velvollisuuksien ja kansalaisten oikeuksien välillä pyritään täyttämään muuttamalla ja tehostamalla kansalaiskasvatusta. Matti Vanhasen ensimmäisen hallituksen neljä vuotta kestäneessä Kansalaisvaikuttamisen politiikkaohjelmassa (2004) havaitaan valtiovallan pyrkimys vahvistaa legitimiteettiään kasvatuksellisin keinoin. Hallitusohjelma tähtäsi edustuksellisen demokratian uskottavuuden vahvistamiseen ja kansalaisyhteiskunnan aktivoimiseen (Ahonen \& Rantala 2005, 11). Ohjelman yhtenä tärkeimpänä tavoitteena oli nuorten kasvu aktiiviseen ja kriittiseen kansalaisuuteen, johon pyrittiin muun muassa parantamalla kansalaistaitojen opetusta ja aktiivisen vaikuttamisen toimintaedellytyksiä (Kansalaisvaikuttamisen politiikkaohjelma 2004). Kansalaiskasvatuksen tehostamisen lisäksi ohjelmalla haluttiin lisätä kansalaisten luottamusta hallintoon parantamalla heidän tiedonsaantiaan ja vaikutusmahdollisuuksiaan.

Yrittäjyyden liittäminen aktiivisen kansalaisuuden piiriin (Perusopetuksen opetussuunnitelman perusteet 2004) kertoo kiinnostavasti kansalaisuuden määritelmän muutoksesta. Yrittäjyys yhdistää kansalaisuuden työntekoon ja kuluttajuuteen, kaventaen samalla kansalaisuuden poliittista ulottuvuutta, ja luo kuvan kansalaisesta itsenäisenä (yksilö)toimijana - "oman onnensa seppänä" - joka ei odota valtion palveluita (Tomperi \& Piattoeva 2005). Aktiivisella kansalaisuudella on näin ollen kiinnostava kaksoismerkitys. Yhtäältä se tarkoittaa aktiivista vastuunottamista yhteiskunnan tulevaisuudesta, mutta toisaalta se merkitsee velvoitetta olla "itsenäinen riskienhallinnan yksikkö" (Saastamoinen \& Kuusela 2006, 143). Aktiivisen kansalaisuuden ihannointi pyrkii sitomaan ihmiset yhteiseen vastuuseen, jonka taustalla on jälleen kerran hyvinvointivaltion kriisiytymisestä johtuva kansalaisten ja valtion välisen siteen heikentyminen.
Koulutuspoliittisten komiteoiden jäsenet keskittyivät miettimään suomalaisuutta ja kansallista identifioitumista muuttuvassa Suomessa. Kuten Suutarinen $(2000,43)$ kirjoittaa, yhteiskunnallisen opetuksen saama huomio on vähäistä tilanteessa, jossa yhteiskuntarauha ja kansallinen yhteenkuuluvuus koetaan vahvaksi. 1990-luvulla tultiin kuitenkin tilanteeseen, jossa Euroopan unioni, maahanmuuttajat ja maan sisäinen muuttoliike asettivat uusia haasteita yhteiskunnalliselle kasvatukselle. Uusi tilanne synnytti muun muassa etnosentrismiä ja rasismia. Samalla yhtenäisyyttä ylläpitävät kertomukset ja vanhat uhkakuvat eivät enää toimineet. (sama.) Asiakirjojen puhe kansallisesta identiteetistä on suoraan tulkittavissa huoleksi kansallisen sosialisaation sisällöistä ja sen onnistumisesta "perinteisen yhtenäiskulttuurin murtuessa" (vrt. Koulutus ja tutkimus 2003-2008). Se, mikä vielä 1980-luvun puolivälissä näytti itsestään selvältä, kuten suomalaisen arvopohjan pysyvyys ja isänmaan itsenäisyys, muuttui 1990-luvun murrosten seurauksena yhä epävarmemmaksi:

"Kansallisen kulttuurin ja kansallisten arvojen kannalta tärkeiden valmiuksien kehittämisessä pyritään kansallisen identiteetin vaalimiseen ja vahvistamiseen. Koulukasvatus pyrkii ohjaamaan oppilasta tietoisuuteen siitä, että hän on yksilönä osa kansakuntaa, jonka jäseniä yhdistävät yhteinen kulttuuriperinne ja itsenäinen isänmaa elinympäristönä." (Peruskoulun opetussuunnitelman perusteet 1985,12 .)

"Kansainvälistyminen ja väestön liikkuminen - uuskansainvaellus - tuovat kulttuuri- ja arvopohjaan uusia aineksia ja edellyttävät omien näkemystemme tarkistamista. Kansallisen kulttuuriperinteen vaaliminen sekä kansainvälisyyteen liittyvä monikulttuurisuus merkitsevät uudenlaista identiteetin selkeyttämistä." (Perusopetuksen opetussuunnitelman perusteet 1994, 8-9.)

1990-luvun dokumenteissa etsitään kuin etsitäänkin vastauksia kysymykseen, mikä on kansakunnan koossa pitävä (uusi) voima. Huoli kansallisesta kulttuuriperinteestä ei siis liity ainoastaan väestön monikulttuuristumiseen tai pienen maan kulttuuri- 
perinteen haurauteen globalisaation puristuksessa. Suomessa kansallinen kulttuuri ja valtion itsenäisyys on vahvasti liitetty yhteen, onhan 1800-luvun lopulla alkaneita itsenäistymispyrkimyksiä perusteltu nimenomaan ainutlaatuisen kansallisen kulttuurin olemassaololla ja sen vaalimisen tärkeydellä (esim. Pulkkinen 1999). Käänteisesti 1980-luvun loppupuolella alkanutta eurooppalaistumista on kritisoitu ennen kaikkea sen vuoksi, että valtiollisen itsenäisyyden menettämisen pelättiin vaarantavan suomalaisen kulttuurin jatkuvuuden (esim. Ruuska 1999). Kansallisen itsenäisyyden epämääräistyessä kansallisen yhtenäisyyden perustaksi tarjotaan elinvoimaista suomalaista kulttuuria, joka on kehittynyt vuorovaikutuksessa eurooppalaisen kulttuurin kanssa. Tämä ajatus on osuvasti kiteytetty yhdessä koulutuspoliittisessa dokumentissa sanoin "kulttuuri korvaa osin valtion yhteisön koossapitävänä voimana, äidinkieli voittaa isänmaan"” (Humanistis-yhteiskuntatieteellisen yleissivistyksen komitean mietintö 1993, 31). Äidinkielen opetukselle onkin Euroopan unioniin liittymisen myötä langetettu erityinen tehtävä syventää kansallista kulttuuritietoisuutta (Palmu 2002, 119).

\section{KANSALAISKASVATUS VENÄJÄLLÄ}

Neuvostoliiton hajoamisen seurauksena koulutusjärjestelmän reformien yhtenä merkittävänä julkilausuttuna päämääränä oli sen peripoliittisen luonteen keventäminen. Esimerkiksi vospitanije-termi, joka suomennettuna merkitsee kasvatusta, tarkoitti neuvostoliittolaisissa kasvatuksellisissa käytännöissä pedagogista toimintaa sosialistisen järjestelmän jäsenten valmentamiseksi. Termin käyttö väheni huomattavasti 1990-luvun alussa. Kasvatuksen ensisijaiseksi tavoitteeksi määritettiin opetus, tarkoittaen sillä "neutraalia" oppisisältöjen välittämistä oppilaille (Piattoeva 2005). Jo 1990-luvun puolivälissä vospitanije nousi uudestaan keskusteluun yhteiskunnallisen eheyden säilyttämisen merkityksessä. Erityisesti sosioekonomista epävakautta, etnisiä konflikteja, median vapautumista ja uskonnon roolin voimistumista pidettiin tärkeinä syinä koulujen kasvatuksellisen toiminnan tarpeellisuudelle. Myöhemmin 2000-luvulla julkaistuissa patrioottisen kasvatuksen ohjelmis- sa kansalaiskasvatuksen tarpeellisuutta perusteleviin syihin lisättiin valtion yhtenäisyyden ylläpitäminen ja valtion ja kansalaisen välisen suhteen vahvistaminen. Kuten suomalaisissa asiakirjoissa myös venäläisten koulutuspoliittisten dokumenttien analyysi tuo ilmi kansalaiskasvatuksen roolin kansallisen yhtenäisyyden ja vakauden ylläpitäjänä.

1990-luvun alun dokumenteissa kansalaiskasvatuksella tarkoitettiin ennen kaikkea lainsäädännön ja kansalaisoikeuksien tuntemusta parantavaa opetusta. Toisin sanoen tuoreen valtiovallan legitimiteetti oli tarkoitus rakentaa itsehallinnan periaatteelle korostamalla kansalaisten osallistumista demokraattiseen päätöksentekoon (Piattoeva 2005). Samaan aikaan koko Venäjän väestöä yhdistävä kansallinen identiteetti jäi vaille huomiota tai tarkemmin sanottuna se määriteltiin Neuvostoliitossa vakiintuneen käytännön tapaan etniseksi identiteetiksi. 1990-luvun alussa, monen entisen neuvostotasavallan juuri itsenäistyttyä, uuden Venäjän yhtenäisyyttä pidettiin hyvin hauraana. Entisten tasavaltojen itsenäistymisen myötä Venäjän väestön etninen rakenne muuttui homogeenisemmaksi, mutta edelleen noin 20 prosenttia Venäjän kansalaisista kuului 1980-luvun lopun tilastojen mukaan muuhun kuin etnisesti venäläisten ryhmään (Sakwa 2008). Maan koossapitämiseksi vallanpitäjät suosivat kansallisuuspolitiikkaa, joka tähtäsi etnisten ryhmien oman identiteetin vahvistumiseen. Opetussuunnitelmien uudistukset toivat mukanaan uuden alueellisen komponentin, joka mahdollisti oman äidinkielen, perinteiden ja historian opiskelun valtiollisen koulutusjärjestelmän puitteissa. Etnisten identiteettien lujittamiseen tähtäävää opetusta pidettiin merkittävänä valtiollista yhtenäisyyttä rakentavana tekijänä ja tämäntyyppisen opetuksen tarpeellisuutta perusteltiin sen valtiota koossapitävällä vaikutuksella (Piattoeva 2009). Valtion koossapitämisen tarve johti 1990-luvun lopulla kuitenkin toisenlaiseen kansalaiskasvatuspolitiikkaan.

1990-luvun loppupuolella koulutuspoliittisissa dokumenteissa alettiin korostaa valtion vastuuta kasvatuksellisesta toiminnasta, vospitanijesta. Tarkoituksena ei niinkään ollut perheiden kasvatusvastuun vähentäminen kuin etnisten ryhmien vaikutusvallan supistaminen. Samaan aikaan etnisiä identiteettejä 
vahvistava koulutuspolitiikka alkoi saada osakseen kritiikkiä. Useammassa koulutuspoliittisessa dokumentissa korostettiin etnisiä identiteettejä vaalivan opetuksen horjuttavia vaikutuksia kansalliseen yhtenäisyyteen (Piattoeva 2009):

"Etninen tekijä on saavuttanut merkittävän aseman yhteiskunnallisessa kehityksessä. Yhtäältä tämä kertoo etnisen kontekstin kasvatuspotentiaalista, mutta toisaalta se pahentaa etnisiä jännitteitä." (Venäjän koulutusjärjestelmän kasvatuksen kehittämisohjelma 1999, 3).

2000-luvulla koulut määrättiin opettamaan Venäjän kansallislaulua sekä Venäjän lipun ja muiden kansallisten symbolien syntyhistoriaa. Samaan aikaan valtion taholta julkaistiin patrioottista kasvatusta ja Venäjän kielen asemaa koskevia poliittisia ohjelmia, joiden argumentointitapa ja sisällöt erosivat merkittävästi vastaitsenäistyneen Venäjän kansalaiskasvatuksen sisällöistä. Etnisiin identiteetteihin liittyen Patrioottisen kasvatuksen käsitekirjassa (2003) kirjoitettiin seuraavasti: "Patriotismi tulee esiin ihmisen toiminnassa. Se saa alkunsa rakkaudesta 'pientä äitimaata' kohtaan. Patrioottiset tunteet nousevat monen kehitysvaiheen kautta täysikasvuisuuteen saavuttaen valtionlaajuisen patrioottisen tietoisuuden ja tietoisen rakkauden isänmaata kohtaan". (Patrioottisen kasvatuksen käsitekirja 2003, 3).

Patrioottisen kasvatuksen ohjelmien perimmäinen tavoite on valtiovallan legitimiteetin ja kansalaisten uskollisuuden lujittaminen. Kansallisuus-termi, kuten sen alatermit, esimerkiksi kansalliset arvot, saavat 2000-luvun dokumenteissa uuden merkityksen Venäjän laajuisina kategorioina. Nimenomaan kansallisen identiteetin pitäisi edustaa kansalaisen ensisijaista identiteettiä. Yhtä aikaa kansalaisten demokraattisia tietotaitoja käsittelevien dokumenttien määrän laskun kanssa tilalle nousi patrioottisen kasvatuksen asiakirjojen uudenlainen tapa nähdä kansalaisen arvot ja toiminnan muodot. Dokumenteissa painotetaan alistumista aktiivisen osallistumisen sekä konsensusta mielipiteiden monimuotoisuuden sijaan. Oikeuksien tilalle on tullut kansalaisen vastuu maansa puolustamisesta ja uskollisuus valtiovallalle. Patrioottista kasvatusta käsittelevien doku- menttien viittaukset armeijaan ja sotilaisiin voidaan katsoa edustavan uudenlaista kansalaisideaalia, jonka keskeisinä hyveinä ovat uskollisuus, uhrautuvaisuus ja vastuun kantaminen (Piattoeva 2009): "Patriotismi tarkoittaa äitimaan rakkautta, uskollisuutta isänmaata kohtaan, pyrkimystä palvella sen etuja ja valmiutta puolustaa sitä uhrautumista myöten" (Patrioottisen kasvatuksen käsitekirja 2003, 2).

"Patriotismi tarkoittaa kansalaisten tietoista ja vapaaehtoista asennetta, jossa yhteiskunnallisen ja valtiollisen etusija eivät rajoita, vaan toimivat henkilökohtaisen vapauden kannustimena ja kansalaisyhteiskunnan monipuolisen kehityksen ehtona." (sama, 3).

\section{LOPUKSI}

Elämme globaalia aikaa, jolloin valtiorajojen merkityksen oletetaan yhä vähentyvän. Kuten Kennedy (2008) osuvasti kiteyttää, koululaitos väittää valmentavansa nuoria sukupolvia globaaleille työmarkkinoille panostamalla vieraiden kielten opiskeluun, tietotekniikan osaamiseen ja suvaitsevaisuuteen erilaisia kulttuureja kohtaan, mutta samalla se pyrkii iskostamaan heihin perikansallisia arvoja ja kansallista uskollisuutta. Näin ollen globalisaatio ja kansainvälistyminen eivät johda kansallisen retoriikan häviämiseen. Suomalaisen aineiston perusteella voidaan jopa väittää, että kansallisen kulttuurin merkitys päinvastoin voimistuu eurooppalaistumisen ja talouden kansainvälistymisen myötä. Kansakunnan elinvoimaisuus ei enää niinkään riipu kansallisvaltion suvereniteetista vaan kansallisen kulttuurin vahvuudesta. Historiallisista ja yhteiskuntapoliittisista eroistaan huolimatta sekä Suomi että Venäjä antavat edelleen suuren arvon kansalaisuudelle ja kansalliselle identiteetille. Samalla ne luottavat valtiollisen koulutusjärjestelmän kykyihin toimia valtiollisen legitimiteetin pönkittäjänä.

Venäjän tapauksessa keskustelut kansallisuudesta, kansalaisuudesta ja kansalaiskasvatuksesta eivät johdu ulkoapäin ohjautuvista muutoksista vaan Neuvostoliiton romahtamisesta aiheutuneesta sisäpoliittisesta tarpeesta rakentaa uudelleen kansalaisten ja valtion välinen suhde. Valtion legitimiteetin 
muutokset johtivat kahteen hyvin erilaiseen tapaan käsitteellistää kansalaiskasvatusta. Nämä tavat vallitsivat eri ajanjaksoina ja kuvastavat ennen kaikkea poliittisen ilmapiirin muutoksia valtaa pitävän ryhmän vaihtuessa. Toisin sanoen poliittisen kentän vakiintumattomuus näkyy Venäjällä kansalaiskasvatuksen sisällöissä siten, että poliittisen johdon vaihdos muuttaa niitä radikaalilla tavalla. Tästä näkökulmasta katsottuna Venäjän kansalaiskasvatuspolitiikka vaihtuvine sisältöineen ja argumentteineen paljastaa selkeämmin kansalaiskasvatuksen luonteen kilpailevien poliittisten ideaalien kohtauspaikkana. Suomen tapauksessa yhteiskunnallisten muutosten suhteellisen maltillinen vauhti ja poliittisen järjestelmän vakaus tarkoittavat sitä, että kansalaiskasvatuksen kehityssuunta on 1990-2000-luvulla pysynyt samana hallitusten vaihtumisesta huolimatta.

Pedagogisten oppimissisältöjen uudistamisen lisäksi 2000-luvulla vakiintunut kansalaiskasvatuspoliittinen retoriikka esittää laajemman yhteiskunnallisen muutoksen. Venäjä näyttäisi irtautuneen 1990-luvun alun demokraattisesta kurssista ja liikkuneen kohti vahvempaa keskusvaltiota, joka odottaa kansalaistensa uskollisuutta ilman vastavuoroisuutta. Kansalaisten ja valtion välisen suhteen muutos kansalaisten velvollisuuksia korostavaksi näkyy myös Suomessa ja johtuu hyvinvointivaltion kriisiytymisestä. Aktiivisen ja yritteliään kansalaisuuden muodossa kansalaisen märïitelmä laajenee tarkoittamaan itsenäistä vastuunkantamista omasta elämästä.

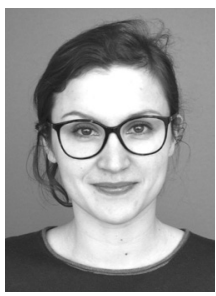

Nelli Piattoeva

KT, tutkijatohtori

Tutkijakollegium,

Yhteiskuntatutkimuksen Instituutti

Tampereen yliopisto

\section{LÄHTEET}

Aapola, S., Gordon, T. \& Lahelma, E. (2003). Citizens in the text? International presentations of citizenship in textbooks. Teoksessa Torres, C.A. \& Antikainen,

A. (toim.) The international handbook on the sociology of education. Maryland: Rowman \& Littlewood Publishers, 381-397.

Ahonen, S. \& Rantala, J. (2005).

Kansalaisvaikuttamisen politiikkaohjelma

yliopistojen opettajankoulutuksessa.

Teoksessa Rantala, J. \& Siikaniva, A. (toim.)

Kansalaisvaikuttaminen opettajankoulutuksen

haasteena. Helsinki: Hakapaino.

Alasuutari, P. (1998). Taide, viihde, kulttuuri ja kansakunta. Teoksessa Alasuutari, P. \& Ruuska, P. (toim.) Post Patria. Globalisaation kulttuuri Suomessa. Tampere: Vastapaino, 132-162.

Arthur, J., Davies I. \& Hahn, C. (2008). (toim.) Handbook of education for citizenship and democracy. Los Angeles: Sage.

Beissinger, M.R. (2005). Pereosmisleniie imperii posle raspada Sovetskogo Soyuza. Ab Imperio 3 http:// abimperio.net/cgi-bin/aishow.pl?state=showa\&idart $=1353$ \&idlang $=2 \&$ Code $=$ (viitattu 5.3. 2010) .
Bottery, M. (2003). The end of citizenship? The nation state, threats to its legitimacy, and citizenship education in the twenty-first century. Cambridge Journal of Education 33(1), 101-122.

Breslauer, G.W. \& Dale, C. (1997). Boris Yeltsin and the invention of a Russian nation-state. Post-Soviet Affairs 13(4), 303-332.

Brubaker, R. (2005 [1996]). Nationalism reframed. Nationhood and the national question in the new Europe. Cambridge: Cambridge University Press.

Brunell, V. \& Törmäkangas, K. (2002). (toim.) Tulevaisuuden yhteiskunnan rakentajat. Yhteiskunnallisen opetuksen kansainvälinen tutkimus Suomen näkökulmasta. Jyväskylä: Jyväskylän yliopisto.

Civics-tutkimus (1999). http://ktl.jyu.fi/arkisto/civics/ civics99/ (viitattu 23.10.2004).

Edwards, R., Nicoll, K., Solomon, N. \& Usher, R. (2004). Rhetoric and educational discourse. Persuasive texts? London ja New York: Routledge Falmer.

Frazer, E. (1999). Introduction: the idea of political education. Oxford Review of Education 25(1/2), 5-23. 
Green, A. (1990). Education and state formation. New York: St. Martin's Press.

Hobsbawm, E.J. (1987). The age of empire 1875-1914. New York: Vintage Books.

Humanismin paluu tulevaisuuteen: humanistisyhteiskuntatieteellisen yleissivistyksen komitean mietintö (1993). Helsinki: Painatuskeskus.

Isin, E.F. \& Turner, B.S. (2007). Investigating citizenship: an agenda for citizenship studies. Citizenship Studies 11(1), 5-17.

Kansalaisvaikuttamisen politiikkaohjelma (2004). http:// www.om.fi/20440.htm

Kansallinen sivistysstrategia (1993). Opetusministeriön asiantuntijaryhmän ehdotus sivistyspolitiikan perustaksi. Helsinki: Opetusministeriö

Kennedy, K.J. (1997) Citizenship education in review. Past perspectives and future needs. Teoksessa Kennedy, K. (toim.) Citizenship education and the modern state. London: The Falmer Press, 1-5.

Kennedy, K.J. (2008) Globalised economies and liberalised curriculum: new challenges for national citizenship education. Teoksessa: Grossman, D.L.; Lee W.O. \& Kennedy, K.J. (toim.) Citizenship curriculum in Asia and Pacific. Hong Kong: Springer, University of Hong Kong, Comparative Education Research Centre, 13-26.

Koulutus ja tutkimus 2003-2008 (2004). http://www. minedu.fi/export/sites/default/OPM/Julkaisut/2004/ liitteet/opm_190_opm06.pdf?lang=fi lviitattu 15.8.2008).

Kuusela, P. \& Saastamoinen, M. (2006). Kansalaisuuden ulottuvuudet. Teoksessa Saastamoinen, M. \& Kuusela, P. (toim.) Kansalaisuuden ääriviivoja. Hallinta ja muodonmuutokset myöhäismodernilla ajalla. Helsinki: Yliopistopaino, 9-25.

Kymlicka, W. \& Straehle, C. (1999). Cosmopolitanism, nation-states and minority nationalism: a critical review of recent literature. European Journal of Philosophy 7(1), 65-88.

Liikanen, I. (1997). Kansalaisen synty. Fennomania ja modernin politiikan läpimurto. Tiede \& Edistys 4. 342-351.

Massialas, B.G. (1977). Education and political development. Comparative Education Review (kesäkuu/lokakuu), 274-295.

Olssen, M., Codd, J. \& O'Neill, A-M. (2004.) Education policy: globalization, citizenship and democracy. London: Sage.

Paasi, A. (1998). Koulutus kansallisena projektina. 'Me' ja 'muut' suomalaisissa maantiedon oppikirjoissa. Teoksessa Alasuutari, P. \& Ruuska, P. (toim.) Elävänä Euroopassa: muuttuva suomalainen identiteetti. Tampere: Vastapaino, 215-250.
Palmu, T. (2002). Suomalaisuus, isänmaa ja äidinkieli. Teoksessa Gordon, T., Komulainen, K. \& Lempiäinen K. (toim.) Suomineitonen hei! Kansallisuuden sukupuoli. Tampere: Vastapaino, 118-132.

Parrott, B. (1997). Analysing the transformation of the Soviet Union in comparative perspective. Teoksessa Dawisha, K. \& Parrott, B. (toim.) The end of empire? The transformation of the USSR in comparative perspective. New York: M.E. Sharp, 3-29.

Patrioottisen kasvatuksen käsitekirja (2003) http://www. ed.gov.ru/junior/rub/patriot/ (viitattu 13.10.2008). [venäjäksi]

Peruskoulun opetussuunnitelman perusteet (1985). Helsinki: Valtion Painatuskeskus.

Perusopetuksen opetussuunnitelman perusteet (1994). Helsinki: Painatuskeskus.

Perusopetuksen opetussuunnitelman perusteet (2004). http://www.oph.fi/saadokset_ja_ohjeet/ opetussuunnitelmien_ja_tutkintojen_perusteet/ perusopetus (viitattu 19.8.2008).

Piattoeva, N. (2005). Citizenship education as an expression of democratization and nation-building processes in Russia. European Education 37(3). 38-52.

Piattoeva, N. (2009). Citizenship and nationality in changing Europe: a comparative study of the aims of citizenship education in Russian and Finnish national education policy texts. Journal of Curriculum Studies 41(6), 723-744.

Piattoeva, N. (2010a). Citizenship education policies and the state. Russia and Finland in a comparative perspective. Tampere: Tampereen yliopisto. (http:// acta.uta.fi /teos.php?id=11377).

Piattoeva, N. (2010b). Citizenship education and intergovernmental organizations: contrasting the national model to the emerging post-national agenda. Teoksessa Holmarsdottir, H.B. \& O’Dowd, M. (toim.) Nordic voices. Teaching and researching comparative and international education in the Nordic countries. Rotterdam: Sense Publishers, 59-74.

Pulkkinen, T. (1999). Kielen ja mielen ykseys. Teoksessa Lehtonen, T. (toim.) Suomi outo pohjoinen maa? Porvoo: PS-Kustannus, 118-137.

Saastamoinen, M. \& Kuusela, P. (2006). Kohti myöhäismodernin kansalaisuuden haasteita. Teoksessa Saastamoinen, M. \& Kuusela, P. (toim.) Kansalaisuuden ääriviivoja. Hallinta ja muodonmuutokset myöhäismodernilla ajalla. Helsinki: Yliopistopaino, 137-149.

Sakwa, R. (2008). Russian politics and society. 4. painos. New York: Routledge.

Sigel, R. S. (1995). New directions for political socialization research. Perspectives on Political Science 24(1), 17-22. 
Skocpol, T. \& Somers, M. (1980). The uses of comparative history in macrosocial inquiry. Comparative Studies in Society and History 22(2), 174-197.

Smith, A.D. (1998). Nationalism and modernism: A critical survey of recent theories of nations and nationalism. London: Routledge.

Suny, R.G. \& Martin, T. (2001). Introduction. Teoksessa Suny, R.G. \& Martin, T. (toim.) A state of nations. Empire and nation-making in the age of Lenin and Stalin. New York: Oxford University Press, 3-20.

Suutarinen, S. (2000). Yhteiskunnallisen opetuksen asema Suomessa. Teoksessa Suutarinen, S. (toim.) Nuoresta pätevä kansalainen. Jyväskylä: Jyväskylän yliopistopaino.

Ronkainen, J. (2009). Väliviivakansalaiset. Monikansalaisuus asemana ja käytäntönä. Joensuu: Joensuun yliopisto.

Ruuska, P. (1999). Muuttuva käsitys kansakunnasta. Teoksessa Alasuutari, P. \& Ruuska, P. (toim.) Post Patria. Globalisaation kulttuuri Suomessa. Tampere: Vastapaino, 71-107.

Tilly, C. (1984). Big structures, large processes, huge comparisons. New York: Russell Sage Foundation.

Tomperi, T. \& Piattoeva, N. (2005). Demokraattisten juurten kasvattaminen. Teoksessa Kiilakoski, T.; Tomperi, T. \& Vuorikoski, M. (toim.) Kenen kasvatus. Kriittinen pedagogiikka ja toisin kasvatuksen mahdollisuus. Tampere: Vastapaino, 247-287.

Venäjän koulutusjärjestelmän kasvatuksen kehittämisohjelma (1999) http://www.edu.ru/db/mo/ Data/d_99/n574.html (viitattu 13.10.2008) [venäjäksi]

\section{VIITTEET}

1 Suomen tapauksessa on muistettava kahden kielen virallinen asema, joka ei kuitenkaan kumoa sitä tosiseikkaa, että kansanvaltaisen valtion toimivuuden kannalta kansalla on oltava yhteinen kieli. Kielen tärkeys näkyy nationalismin yleishistoriassa tavoitteellisena politiikkana poistaa alueelliset kielet ja murteet yhtenäisen virallisen valtiokielen tieltä (esim. Hobsbawm 1987).

2 Analysoin yhteensä 41 venäläistä asiakirjaa (480 sivua) ja 15 suomalaista (590 sivua). 